\title{
Effect of a short period of high day temperatures during flowering on the seed number per pod of pea (Pisum sativum L)
}

\author{
MH Jeuffroy ${ }^{1 *}$, C Duthion ${ }^{2}$, JM Meynard ${ }^{3}$, A Pigeaire ${ }^{2}$ \\ 1 INRA, Station d'Agronomie, 78850 Thiverval-Grignon; \\ 2 INRA, Station d'Agronomie, 17 rue Sully, BP 1540, 21034 Dijon Cedex; \\ 3 Institut National Agronomique Paris-Grignon, 16, rue Claude Bernard, 75231 Paris Cedex 05, France
}

(Received 28 March 1988; accepted 22 December 1989)

\begin{abstract}
Summary - Pea seeds were grown in a glasshouse and subsequently transferred to and grown in an environmentally controlled growth chamber $\left(20^{\circ} \mathrm{C}\right.$ day, for $16 \mathrm{~h} ; 13^{\circ} \mathrm{C}$ night, for $\left.8 \mathrm{~h}\right)$. Seven days after anthesis, plants were exposed to 28 or $31^{\circ} \mathrm{C}$ for $6 \mathrm{~h}$ during the middle of the day, for 2 or 4 consecutive days. Control plants were maintained at $20^{\circ} \mathrm{C}$. Elevated temperatures did not influence growth and development of the leaves, flowers, or the number of pods per plant. However, they reduced the number of seeds per pod. By categorizing the different stages of flower and pod development at the time of elevated temperature treatment, we determined that developing seeds were thermally sensitive from about 6-12 days after the flower opened. Developing seeds exposed to high temperature during this period aborted and the net result was a reduction in pea seed yield. Extrapolating these data to field conditions we suggest relevant criteria to diagnose an effect of high temperature where reduced yields are obtained.
\end{abstract}

growth / development / yield / seed abortion / critical thermoperiod / field diagnosis

Résumé - Effet d'une courte période de hautes températures diurnes pendant la floraison sur le nombre de graines par gousse du pois protéagineux (Pisum sativum L). Des pois ont été cultivés en serre, puis en chambre de culture $\left(16 \mathrm{~h}\right.$ de jour à $20^{\circ} \mathrm{C} ; 8 \mathrm{~h}$ de nuit à $\left.13^{\circ} \mathrm{C}\right)$. Sept jours après le début de la floraison, une partie des plantes a été soumise, pendant 2 ou 4 j consécutifs, à des températures élevées, 28 ou $31^{\circ} \mathrm{C}$; la période de traitement était de $6 \mathrm{~h}$ au milieu de la photophase. Les autres plantes, maintenues à $20^{\circ} \mathrm{C}$, servaient de témoins. Ni le développement (émission des feuilles (tab II), progression de la floraison (tab III) et du stade limite d'avortement (fig 1)), ni la croissance des plantes (tab $I V$ ), ni le nombre de gousses par plante (tab IV) n'ont été atteints par la contrainte thermique. En revanche, le nombre de graines par gousse est significativement affecté par les hautes températures (fig 2). En regroupant les fleurs et les gousses selon le stade de développement qu'elles avaient atteint au début du traitement, on détermine que les graines sont sensibles aux hautes températures entre 6 et $12 j$ après ouverture de la fleur. Des graines en développement, soumises à des hautes températures pendant cette période, avortent, ce qui réduit le rendement en graines. Cette étude permet de définir les variables pertinentes à mesurer sur la plante, pour diagnostiquer un effet des températures élevées, au champ.

développement / croissance / rendement / avortement de graines / période critique / diagnostic cultural

\section{INTRODUCTION}

Various workers have shown that elevated ambient temperatures during a large part of the pea cycle subsequently reduced pea plant growth, the number of flowering nodes, the number of pods per plant and seed yield (Boswell, 1926; Stanfield et al, 1966; Nonnecke et al, 1971). Temperatures of $30^{\circ} \mathrm{C}$ for 1 day, or 27 or $29^{\circ} \mathrm{C}$ for 3 days at the time of flowering produced a reduction in the number of seeds per plant (Lambert and Linck, 1958; Karr et al, 1959). These workers suggested that seed development was most affected when plants were subjected to high temperatures 5-10 days after opening of the flower at the first node. However, they did not indicate if elevated temperature for short

"Correspondence and reprints 
durations reduced plant growth or the number of fruitful nodes (the control plants, not exposed to high temperature, had in general only one fruiting-node).

High temperatures during flowering has been suggested as a cause of yield variation. For example, in an analysis of a chronological series of pea yields, Pumphrey et al (1979) deduced that high temperatures reduced yield. They based their deduction on the strong negative correlation between yield and the variable $\Sigma\left(T_{\max }-25.6\right)$, calculated between flowering and harvest. In France during 1986 temperatures exceeded $30^{\circ} \mathrm{C}$ during flowering; according to some workers, this may have explained the poor yields obtained in certain parts of the Paris basin. These "heat waves" would have produced a cessation in flowering and consequently a reduction in the number of fruitful nodes and the number of pods per plant (Duthion et al, 1987; Laconde et al, 1987).

Yet the correlation of elevated temperature and yield reduction remains hypothetical and elusive. Pea yield is a multi-faceted complex of environmental variables. Also, one cannot exclude that the poor yields may be due to other uncharacterized limiting factors (see Meynard and Sebillotte, 1982). Hence, in order to determine which factor(s) is responsible for the loss of production, it is essential that the characteristic symptoms of its effect on the crop be known and their presence verified.

The objective of our study in developing a diagnostic method for pea crops was to determine the results of elevated temperatures during flowering and to define the characteristic syndrome of their effect. We therefore undertook to clearly define the influence of elevated temperatures on the growth and development of the plant and all the components of seed number per plant.

\section{MATERIALS AND METHODS}

\section{Experimentation: general conditions}

Experiments were carried out in an environmentally controlled growth chamber. Pea seeds and cv Solara were sown in 5-1 pots containing a sample of clay material obtained from the cultivated layer of a brown calcareous soil and enriched in minerals. There was no further mineral application after sowing. There were 8 seeds per pot, which were thinned to 4 plants at the 3-4-leaf stage. To prevent an abnormally small number of reproductive organs from forming, as in the experiments of Lambert and Linck (1958) and Karr et al (1959), and as pea inflorescence structure is dependent on the temperature and photoperiod early in plant development (Pate, 1975; Hole, 1977; Sum- merfield and Wien, 1978), the plants were placed in an unheated glasshouse (average min $9.8^{\circ} \mathrm{C}$, average max $19.3^{\circ} \mathrm{C}$ ) from sowing until the 10 -leaf stage. They were then transferred to a growth chamber maintained at the following environmental conditions: photoperiod: $16 \mathrm{~h}$ of light at a flux of $200 \mu \mathrm{E} \cdot \mathrm{m}^{-2} \cdot \mathrm{s}^{-1}$ (fluorescent lamps) and $8 \mathrm{~h}$ darkness; temperatures: $20^{\circ} \mathrm{C}$ day, $13^{\circ} \mathrm{C}$ night; moisture: the soil was maintained near field capacity; relative humidity: $80-90 \%$.

\section{Treatments}

At flowering, plants were exposed to $28^{\circ} \mathrm{C}$ for 2 or 4 consecutive days for $6 \mathrm{~h}$ during the middle of the light period. At other times, plants were kept at $20^{\circ} \mathrm{C}$. At no time were control plants subjected to elevated temperatures. There were 16 plants per temperature treatment and 24 control plants. A single growth chamber was used for each temperature treatment and individual plants were considered as replications. A second experiment, similar to the first, was carried out, but treatment temperature was at $31^{\circ} \mathrm{C}$. Seeds for the first experiment were sown on March 4 while seeds for the second experiment were sown on February 23.

Heat stress was initiated on the 7th day after onset of flowering (onset of flowering was defined according to Maurer et al (1966), as the stage "0.5" of the first flower at the first flowering node). This date was chosen so that the stage of the second flowering node was included in the period of pod thermosensitivity as defined by Lambert and Linck (1958). At this stage, the pods were formed and linear growth had commenced at the first flowering node; at the second node, the petals had wilted or had abscised and the pod has formed; at the third node, flowers were open and turgid with no visible abscission; at higher nodes, only flower buds were visible.

\section{Measurements}

Plant development was observed before and after each temperature treatment, and on each subsequent day until the final stage in seed abortion (Pigeaire et al, 1986). The number of leaves on each shoot (main stem and branches) and the stage of the last leaf were recorded using the decimal scale of Maurer et al (1966). The progression of flowering and the final stage in seed abortion (FSSA) were recorded as the number of the highest nodes at which these stages were observed. The seed length, characteristic of the final stage in seed abortion is $6 \mathrm{~mm}$ (Duthion and Pigeaire, unpublished observations). When at least one seed at a node had exceeded this length, it was considered that the stage had been completed at this node. Pods were held to the light and the seed viewed through the transparent pod walls. In this manner, seed length was measured non-destructively.

There were 3 harvests: 1), at the beginning of each temperature treatment; 2 ), at termination of the final stage in seed abortion [at this stage, the seed number is fixed and plant dry matter is at its maximum (Pigeaire et al, 1986)]; and 3), at maturity. The position and number of pods on each shoot were recorded for each harvested plant, and the numbers of seeds in each pod were counted. Various plant organs were separated and oven-dried for $24 \mathrm{~h}$ at $80^{\circ} \mathrm{C}$. The dry 
weight of the leaves, pods and seeds of each shoot was recorded. The stems of the whole plant were weighed together. The data were subjected to analysis of variance and mean differences determined using the $t$-test. Each experiment was analyzed separately.

\section{RESULTS}

\section{Evidence for various types of plant morphology and classification}

During the vegetative growth phase and well before treatment differences in the development of the plants were apparent, which were taken into account during analysis of the results. These differences concerned: development of the main stem, which in certain plants ceased at the 8-10-leaf stage; the number of branches; the presence on certain stems of a second flowering appearing after a series of strictly vegetative nodes, which followed the first reproductive nodes formed.
These 3 criteria allowed us to define 8 "plant types" (table I) which also exist in the field in proportions which vary according to the situation (Jeuffroy, unpublished observations). The last 5 poorly represented types were excluded from the analysis. In the 3 other types, analyses of variance were performed by introducing a factor "plant type", which reduced the residual coefficient of variation. The origin of these differences between plants is unknown. It is possible that light and temperature conditions during the vegetative phase (as the division into types is not exactly the same for the 2 sowing dates; see table I), or that the heterogeneity of the seed micro-environment caused this effect.

\section{Effect of elevated temperature on plant growth and development}

Plants maintained at high temperatures for short periods during flowering did not have significantly different numbers of leaves from the control (table II).

Table I. Plant types.

\begin{tabular}{|c|c|c|c|c|}
\hline $\begin{array}{c}\text { Development } \\
\text { of the main stem } \\
\text { normal (t) } \\
\text { or incomplete (-) }\end{array}$ & $\begin{array}{c}\text { Number of branches } \\
\text { per plant }\end{array}$ & $\begin{array}{l}\text { Second flowering } \\
\text { present }(+) \\
\text { or absent }(-)\end{array}$ & \multicolumn{2}{|c|}{$\begin{array}{c}\text { Number of plants } \\
\text { for each } \\
\text { plant type } \\
\text { treatments at: }\end{array}$} \\
\hline+ & 1 & - & 27 & 24 \\
\hline- & 2 & - & 11 & 22 \\
\hline+ & 2 & - & 10 & 7 \\
\hline+ & 1 & + & 4 & 0 \\
\hline+ & 0 & - & 1 & 1 \\
\hline- & 3 & - & 1 & 1 \\
\hline- & 3 & + & 2 & 0 \\
\hline- & 1 & - & 0 & 1 \\
\hline
\end{tabular}

Table II. Influence of brief periods of elevated temperatures on the mean number of leaves per shoot. (y): Values in parentheses indicate the number of shoots; $(z)$ : For a given experiment, means followed by the same letter are not significantly different at the $5 \%$ level ( $t$-test).

Treatments

Main stem
No of leaves per shoot

Branches at 1st node

Branches at 2nd node

$\begin{array}{rl}\text { First experiment } & \\ \text { Control }\left(20^{\circ} \mathrm{C}\right) & 18.6(10) \mathrm{a}(\mathrm{y}, \mathrm{z}) \\ 2 \text { days at } 28^{\circ} \mathrm{C} & 18.6(10) \mathrm{a} \\ 4 \text { days at } 28^{\circ} \mathrm{C} & 19.1(10) \mathrm{a}\end{array}$

Second experiment Control $\left(20^{\circ} \mathrm{C}\right)$

2 days at $31^{\circ} \mathrm{C}$ 4 days at $31^{\circ} \mathrm{C}$
$17.0(7) \quad a^{\prime}$
$17.3(9) \quad a^{\prime}$
$17.2(12) a^{\prime}$

$16.5(15) b$

$16.6(14) b$

$17.0(12) b$

$\begin{array}{ll}15.2(12) & b^{\prime} \\ 16.0(9) & b^{\prime} \\ 15.2(9) & b^{\prime}\end{array}$

$15.4(15) b^{\prime}$

$15.6(14) b^{\prime}$

$15.5(13) b^{\prime}$ 
Table III. Influence of brief periods of elevated temperatures on the mean number of flowering nodes per shoot. $(y)$ : Values in parentheses indicate No of shoots; ( $z$ ) : Means followed by the same letter are not significantly different at the $5 \%$ level $(t$-test).

\begin{tabular}{lcc}
\hline Treatments & \multicolumn{2}{c}{ No of flowering nodes per shoot } \\
& Before treatment & Final No \\
\hline & & $3.5(4) \mathrm{a}(\mathrm{y}, \mathrm{z})$ \\
Control $\left(20^{\circ} \mathrm{C}\right)$ & 2 & $3.6(7) \mathrm{a}$ \\
2 days at $31^{\circ} \mathrm{C}$ & 2 & $3.8(5) \mathrm{a}$ \\
4 days at $31^{\circ} \mathrm{C}$ & 2 & $4.1(20) \mathrm{b}$ \\
& & $4.5(13) \mathrm{b}$ \\
Control $\left(20^{\circ} \mathrm{C}\right)$ & 3 & $4.4(10) \mathrm{b}$ \\
2 days at $31^{\circ} \mathrm{C}$ & 3 & $4.7(9) \mathrm{C}$ \\
4 days at $31^{\circ} \mathrm{C}$ & 3 & $5.2(10) \mathrm{C}$ \\
Control $\left(20^{\circ} \mathrm{C}\right)$ & 4 & $4.9(13) \mathrm{C}$ \\
2 days at $31^{\circ} \mathrm{C}$ & 4 &
\end{tabular}

When categorizing the shoots according to their number of nodes already in flower at the beginning of treatment, treated and control plants had similar total numbers of flowering nodes (table III). Similar results were obtained for both experiments. High temperatures therefore did not cease flowering.

Control plants and those treated at $31^{\circ} \mathrm{C}$ had similar rates of completion of the final stage in seed abortion and numbers of fruiting nodes (fig 1). Plants treated at $28^{\circ} \mathrm{C}$ responded similarly (date not shown).

At the end of the final stage in seed abortion and at maturity, dry weights of the aerial organs

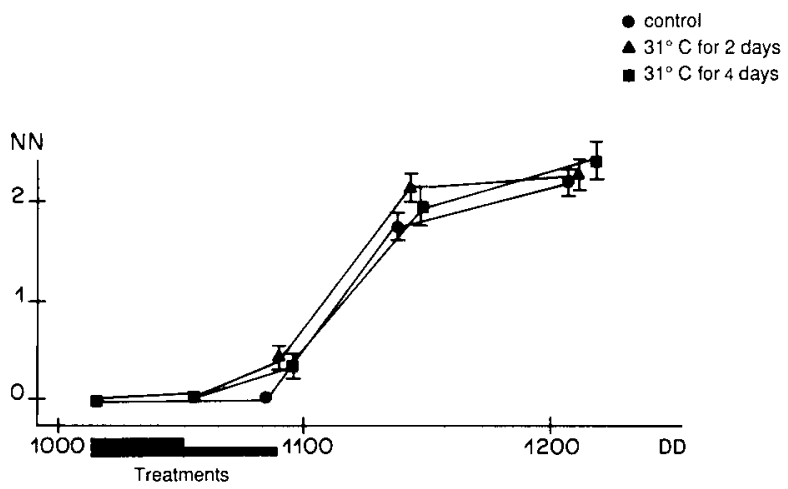

Fig 1. Progression of the final stage in seed abortion. $N N=$ Average number of nodes attaining the final stage in seed abortion; $\mathrm{DD}=$ Total number of degree-days from date of sowing. The vertical bars indicate standard errors. Their absence signifies they are too small to be visible.

excepting the seeds (ie, stems, leaves and pod walls) were similar for the treated and control plants (table IV).

\section{Effect of elevated temperature on number of seeds per plant}

Plants subjected to $31^{\circ} \mathrm{C}$ for 2 or 4 days had significantly reduced numbers of seeds (table IV). Since the number of nodes was not reduced by elevated temperatures, it was concluded that pod or seed abortion had occurred. Whereas the number of pods per plant was not affected, the average number of seeds per pod was significantly reduced by 2 or 4 days of treatment at $31{ }^{\circ} \mathrm{C}$ (table IV). For treatment at $28^{\circ} \mathrm{C}$, no significant variation in numbers of seeds or pods per plant was observed (table IV).

Table IV. Influence of brief periods of elevated temperatures on yield components and vegetative dry matter. $(x):$ FFSA = final stage in seed abortion; $(y)$ : For a given experiment, means in a column followed by the same letter are not significantly different at the $5 \%$ level $(t$-test); $(z)$ : The analysis of variance was carried out using the results of the 2 harvests.

\begin{tabular}{|c|c|c|c|c|c|c|c|c|}
\hline \multirow[t]{2}{*}{ Treatments } & \multirow[t]{2}{*}{ No of plants } & \multirow[t]{2}{*}{$\begin{array}{c}\text { No of seeds } \\
\text { per plant }\end{array}$} & \multirow[t]{2}{*}{$\begin{array}{c}\text { No of pods } \\
\text { per plant }\end{array}$} & \multirow[t]{2}{*}{$\begin{array}{c}\text { No of seeds } \\
\text { per pod }\end{array}$} & \multicolumn{2}{|c|}{$\begin{array}{c}\text { Total plant } \\
\text { dry matter } \\
\text { excepting seeds } \\
(g)\end{array}$} & \multicolumn{2}{|c|}{$\begin{array}{l}\text { No of seeds per } \\
\text { unit of plant dry } \\
\text { matter excepting } \\
\text { seeds }\end{array}$} \\
\hline & & & & & $\begin{array}{c}F S S A \\
(x)\end{array}$ & $\begin{array}{c}\text { Final } \\
\text { harvest }\end{array}$ & FSSA & $\begin{array}{c}\text { Final } \\
\text { harvest }\end{array}$ \\
\hline \multicolumn{9}{|l|}{ First experiment } \\
\hline Control $\left(20^{\circ} \mathrm{C}\right)$ & 15 & 24.7 a $(y)$ & $6.4 \mathrm{a}$ & $3.9 \mathrm{a}$ & 8.0 & $5.0 \mathrm{a}(\mathrm{z})$ & 3.0 & 4.8 a $(z)$ \\
\hline 2 days at $28^{\circ} \mathrm{C}$ & 12 & $25.7 \mathrm{a}$ & $7.2 \mathrm{a}$ & $3.6 \mathrm{a}$ & 6.9 & $5.1 \mathrm{a}$ & 3.4 & $5.2 \mathrm{a}$ \\
\hline 4 days at $28^{\circ} \mathrm{C}$ & 11 & $23.0 \mathrm{a}$ & $6.6 \mathrm{a}$ & $3.6 \mathrm{a}$ & 8.0 & $5.0 \mathrm{a}$ & 3.1 & $4.4 \mathrm{a}$ \\
\hline \multicolumn{9}{|l|}{ Second experiment } \\
\hline Control $\left(20^{\circ} \mathrm{C}\right)$ & 15 & $22.2 a^{\prime}$ & $6.6 \mathrm{a}^{\prime}$ & $3.4 \mathrm{a}^{\prime}$ & 7.4 & $4.2 \mathrm{a}^{\prime}$ & 3.1 & $5.2 a^{\prime}$ \\
\hline 2 days at $31^{\circ} \mathrm{C}$ & 15 & $18.4 b^{\prime}$ & $6.3 a^{\prime}$ & $2.9 b^{\prime}$ & 7.3 & $4.4 \mathrm{a}^{\prime}$ & 2.7 & $4.0 \mathrm{~b}^{\prime}$ \\
\hline 4 days at $31^{\circ} \mathrm{C}$ & 15 & $19.3 a^{\prime} b^{\prime}$ & $6.5 \mathrm{a}^{\prime}$ & $3.0 b^{\prime}$ & 6.4 & $4.6 \mathrm{a}^{\prime}$ & 2.8 & $4.6 a^{\prime} b^{\prime}$ \\
\hline
\end{tabular}



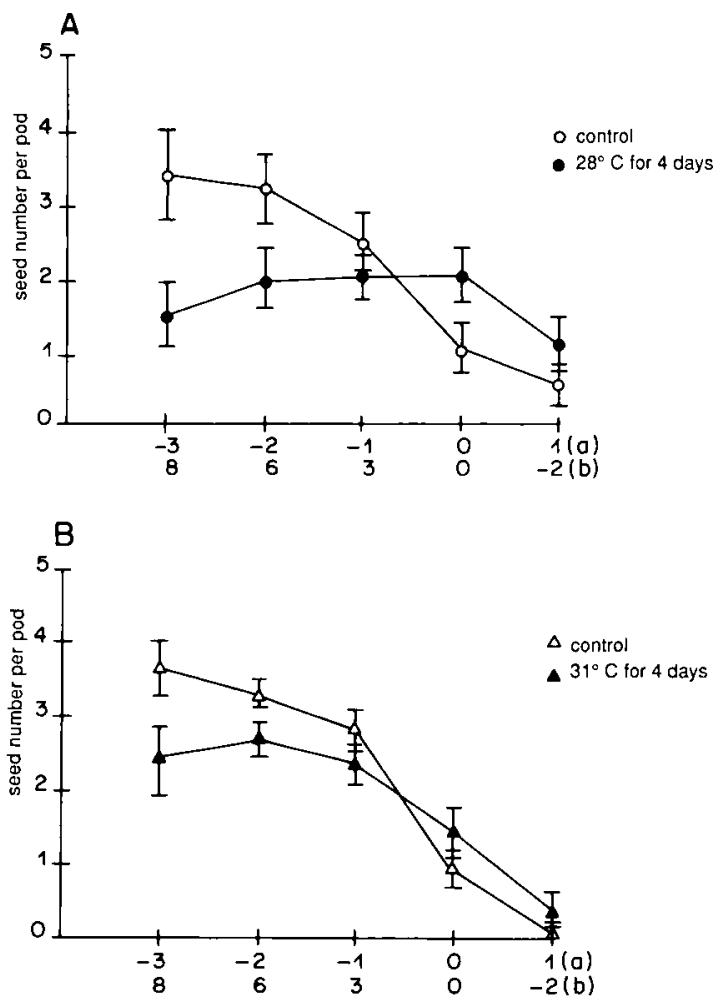

Fig 2. Seed number per pod at each node, according to the stage of the node at the time of treatment application. On the $X$-axis, 0 indicates the node on which flowers opened on the 1st day of treatment, -1 the node below, and +1 the node above. Treatment was at $28^{\circ} \mathrm{C}(\mathrm{A})$ and at $31^{\circ} \mathrm{C}$ (B). (a), node number; (b), No of days between opening of the flower at this node and beginning of temperature treatment. Vertical bars indicate standard errors.

The ratio of the seed number to the weight of dry matter excepting seeds was also reduced by treatment at $31^{\circ} \mathrm{C}$ (table IV).

\section{Effect of elevated temperature on seed number per pod at different nodes}

Nodes were classified according to their developmental stage at the time of elevated temperature treatment (fig 2). The seed number per pod was reduced on older nodes (Nos $-3,-2$ in fig $2 \mathrm{~A}$ and $2 \mathrm{~B}$ ) in plants subjected to 28 and $31^{\circ} \mathrm{C}$ for a 4-day period. Data from plants exposed to elevated temperatures for 2 days are not presented, but means were between those obtained for control and 4-day treated plants. Pods on older nodes $(-2$ and -3$)$ were from flowers which opened 6-8 days before elevated temperature treatments were initiated. The seed number per pod on the younger nodes (number 0 and +1 in fig 2B) was not significantly different from the control in treatment at $31^{\circ} \mathrm{C}$. However, it was significantly increased for treatment at $28^{\circ} \mathrm{C}$. Although an absence of effect of treatment at $28^{\circ} \mathrm{C}$ on the average seed number per pod for the whole plant was noted, a contrasting reaction of the different nodes was found (negative for the older, positive for the younger nodes).

\section{DISCUSSION AND CONCLUSION}

\section{Effect of high temperatures}

Our results confirm that exposure to a temperature of $31^{\circ} \mathrm{C}$ for a short duration significantly reduced the number of seeds per plant. We observed no significant reduction in number of seeds per plant at $28^{\circ} \mathrm{C}$. Lambert and Linck (1958) however, reported reduction in seed numbers when plants were exposed to $27^{\circ} \mathrm{C}$ for 3 days. We ascribe these differences to cultivar response to high temperature. Temperature sensitivity has been noted in other crops, ie soybean cultivars vary in their sensitivity to low temperature (Hume and Jackson, 1981).

The decrease in seed number caused by high temperatures did not cause any perceptible effect on plant growth and development. No inhibition of flowering was noted. In field observations in 1986 cessation of flowering was attributed to high temperatures (Duthion et al, 1987; Laconde et al, 1987) but it was probably due to other factors, possibly water stress (Maurer et al, 1968). Regarding plant growth, the hypothesis of Lambert and Linck (1958) cannot be discounted; that is, high temperatures increase the rate of respiration, reduce the concentration of assimilates for ovule development, or reduce the translocation of assimilates to pods and seeds. However, in our experiment, duration of the treatment must have been too limited to elicit a change in dry weight. On the contrary, Boswell (1926) and Fletcher et al (1966) have shown that plants exposed for long periods to elevated temperatures have a reduction in accumulated dry matter.

Plants exposed to $31^{\circ} \mathrm{C}$ had similar numbers of pods to control plants, but high temperatures reduced the number of seeds per pod. Nonnecke et al (1971) and Stanfield et al (1966) also observed a marked reduction in the number of pods per plant; however, elevated temperatures were maintained throughout the entire life of the plant. Nonnecke et al (1971) reported a smaller reduction in pod numbers when plants were subjected to elevated temperatures at flowering. It appears that under experimental conditions involving prolonged stress, flower initiation took place when the plants were already subjected to high temperatures, resulting in a reduced number of flowers being produced, as suggested by 
Ormrod et al (1970). In another leguminous species, Lupinus angustifolius $\mathrm{L}$, Downes and Gladstones (1984) showed that plants exposed to $33^{\circ} \mathrm{C}$ for 3 or 5 days had reduced pod and seed numbers.

The difference in response of pods at different nodes demonstrates that there is a critical period at which high temperature has an effect on seed development. The critical period begins $\approx 6$ days after the flower opens. Our treatment did not permit determination of the end of this critical period. Yet according to Pigeaire et al (1986), it can be completed at the final stage in seed abortion, 12-13 days after anthesis under the present experimental conditions. Our results agree with those of Lambert and Linck (1958). The behaviour of the youngest pods in the $28^{\circ} \mathrm{C}$ treatment (more seeds than in controls) could be interpreted as the result of compensation, after cessation of thermal stress, for the reduced number of seeds in the older pods. An analogous compensation did not seem to be possible with the plants subjected to $31^{\circ} \mathrm{C}$.

\section{Development of the diagnostic method}

Extrapolation of experimental results obtained in a controlled environment to a field situation is not easy or readily apparent. In an environmentally controlled chamber, all the plants (and flowers) were subjected to identical ambient conditions as defined by the experimental protocol, whereas in the field, the structure of the canopy induces differences in shading (Turc, 1988) and therefore in temperature between pods. Moreover in the field, high day temperatures in a temperate climate are often accompanied by high night temperatures. This was not the situation in our study; night temperatures were maintained constant at $13^{\circ} \mathrm{C}$. Temperatures which may induce similar effects in the field could therefore be slightly different to those in our study.

In the field, climatic factors (ie high temperatures, soil dessication and low relative humidity) are interrelated and have a major impact on plant growth and development. Maurer et al (1968) showed that a lack of moisture at flowering reduced the subsequent number of flowering nodes, the number of pods, the number of seeds per pod and vegetative growth. High temperatures on the contrary did not affect the number of flowering nodes, the number of pods per plant or plant dry matter (aerial organs excepting the seeds). Elevated temperatures caused 2 specific symptoms. First, there was a reduction in the number of seeds produced per unit of total plant dry matter excepting seeds. Second, there was a reduction in the number of seeds per pod on the nodes when 6-day old flowers were exposed to elevated temperatures. Examination of these symptoms in a field situation should allow determination of whether the reduction in seed yield was related to heat stress or not. For this diagnosis, the flowering dates for the different nodes must be known. Varietal references or models are also required, indicating the expected number of seeds per node and the number of seeds per unit of plant dry matter excepting seeds, expected in an environment without elevated temperature. Duthion et al $(1986,1987)$ have begun to collect data on pea cultivars and their environmental responses. The diagnostic method thus consists of comparing actual seed numbers per node or per plant with projected seed numbers. If the projected seed numbers are not obtained, the climatic data are examined to determine if there was a period of elevated temperatures during the sensitive period of seed development. The reduction in seed yield can then be related to heat stress.

\section{REFERENCES}

Boswell VR (1926) The influence of temperature upon the growth and yield of garden peas. Proc Am Soc Hortic Sci 23, 162-168

Downes RW, Gladstones JS (1984) Physiology of growth and seed production in Lupinus angustifolius L. I. Effects on pod and seed set of controlled short duration high temperatures at flowering. Aust J Agric Res 35, 493-499

Duthion C, Ney B, Pigeaire A (1986) Compte-rendu des travaux effectués sur pois de printemps lors de la campagne 1986 (cv Finale, Amino, Solara). Internal report, INRA, Dijon, $22 \mathrm{pp}$

Duthion C, Ney B, Turc O (1987) Compte-rendu des travaux effectués sur pois de printemps lors de la campagne 1987 (cv Finale, Amino, Solara, Frisson). Internal report, INRA, Dijon, $23 \mathrm{pp}$

Fletcher HF, Ormrod DP, Maurer AR, Stanfield B (1966) Response of peas to environment. 1. Planting date and location. Can J Plant Sci 46, 77-85

Hole CC (1977) Environmental control of flower number in multi-flowered cultivars of Pisum sativum L. Ann Bot 41, 1217-1223

Hume DJ, Jackson AKH (1981) Pod formation in soybeans at low temperatures. Crop Sci 21, 933937

Karr EJ, Linck AJ, Swanson CA (1959) The effect of short periods of high temperature during day and night periods on pea yields. Am J Bot 46, 91-93

Laconde JP, Girard C, Maufras JY, Cure B, Plancquaert P (1987) Protéagineux : résultats de l'expérimentation 1986. Perspect Agric 111, 57-66

Lambert RG, Linck AJ (1958) Effects of high temperature on yield of peas. Plant Physiol 33, 347-350 
Maurer AR, Jaffray DE, Fletcher HF (1966) Response of peas to environment. III. Assessment of the morphological development of peas. Can J Plant Sci 46, 285-290

Maurer AR, Ormrod DP, Fletcher HF (1968) Response of peas to environment. IV. Effect of five soil water regimes on growth and development of peas. Can $J$ Plant Sci 48, 129-137

Meynard JM, Sebillotte M (1982) Diagnostic sur les causes de variation du rendement du blé dans une petite région. In: La Fatigue des Sols Coll INRA, Versailles, 21-22 October 1982, 157-168

Nonnecke IL, Adedipe NO, Ormrod DP (1971) Temperature and humidity effects on the growth and yield of pea cultivars. Can J Plant Sci 51, 479-484

Ormrod DP, Maurer AR, Mitchell G, Eaton GW (1970) Shoot apex development in Pisum sativum $L$ as affected by temperature. Can JPlant Sci 50, 201-202

Pate JS (1975) Pea. In: Crop Physiology. Some Case Histories (Evans LT, ed) Cambridge University Press, London, 191-224
Pigeaire A, Duthion C, Turc O (1986) Characterization of the final stage in seed abortion in indeterminate soybean, white lupin and pea. Agronomie 6(4), 548-550

Pumphrey FV, Ramig RE, Allmaras RR (1979) Field response of peas (Pisum sativum $L$ ) to precipitation and excess heat. J Am Soc Hortic Sci 104(4), 548-550

Stanfield B, Ormrod DP, Fletcher HF (1966) Response of peas to environment. II. Effects of temperature in controlled-environment cabinets. Can J Plant Sci 46, 195-203

Summerfield RJ, Wien HC (1978) Effects of photoperiod and air temperature on growth and yield of economic legumes. In: Advances in Legume Science (Summerfield RJ, Bunting $\mathrm{AH}$, eds), British Museum of Natural History, 17-36

Turc $O$ (1988) Elaboration du nombre de graines chez le pois protéagineux (Pisum sativum L), (cv Frisson, Finale et leurs homologues afila): influence du rayonnement intercepté et application au diagnostic cultural. Thèse de Doctorat, USTL Montpellier, $95 \mathrm{pp}$ 